\title{
UNDERWATER CULTURAL HERITAGE IN THE PACIFIC: THEMES AND FUTURE DIRECTIONS
}

\author{
Bill Jeffery* \\ University of Guam, Unibetsedåt Guåhan, College of Liberal Arts and Social \\ Sciences, Humanities, UOG Station, Mangilao, Guam, USA \\ Email: jefferyw@triton.uog.edu
}

\author{
Jennifer F. McKinnon ${ }^{* *}$ \\ East Carolina University, Program in Maritime Studies, Department of History, \\ Greenville, North Carolina, USA \\ Email: mckinnonje@ecu.edu
}

\section{Hans Van Tilburg ${ }^{* * *}$}

National Oceanic and Atmospheric Administration, Office of National

Marine Sanctuaries, Pacific Islands Region, 1845 Wasp Blvd,

Building 176, Honolulu, Hawai i, USA

Email: hans.vantilburg@noaa.gov

Published online: 30 July 2021

To cite this article: Jeffery, B., McKinnon, J. F. and Van Tilburg, H. 2021. Underwater cultural heritage in the Pacific: Themes and future directions. International Journal of Asia Pacific Studies 17 (2): 135-168. https://doi.org/10.21315/ijaps2021.17.2.6

To link to this article: https://doi.org/10.21315/ijaps2021.17.2.6

\begin{abstract}
This article focuses on the underwater cultural heritage (UCH) located across the Pacific Ocean by sampling three temporal themes: living heritage and traditional indigenous cultural heritage, the global connections of the Manila Galleon trade, and the modern warfare of World War II (WWII). Many of the traditional cultural practices (living heritage) and tangible cultural heritage related to indigenous people of the Pacific are coastal and sea related. Their world encompasses the sea, which was not seen as a barrier as but a much-used connection to people occupying the thousands of islands. The Pacific contains an extensive maritime cultural heritage, including $\mathrm{UCH}$, which reflects the cultural identity of people living in the region. From the 16th to 18th centuries, the Spanish Empire prospered through an elaborate Asia-Pacific trade network. The Manila Galleon trade between Manila,


Philippines, and Acapulco, Mexico, connected into the existing Atlantic trade transporting commodities such as porcelain, silver, spices and textiles from Asia to the Americas and Spain. Of the 400 known voyages between 1565 and 1815, approximately 59 shipwrecks occurred, of which only a handful of galleons have been investigated. The scale of WWII heritage in the Pacific region reflects the intensity and impacts of global conflicts fought across the world's largest ocean. Associated UCH includes near shore defensive infrastructure, landing and amphibious assault craft, submerged aircraft, and a wide range of ships and submarines, auxiliary, combatant and non-military casualties alike. Twentieth century warfare involved massive losses of material. The legacy of submerged battlefields in the Pacific is complex. Interest is high in the discovery of naval $\mathrm{UCH}$, but critical aspects are often intertwined. Archaeology, history, reuse, memorialisation (gravesites), tourism, unexploded ordnance, environmental threat (fuel oil), ownership and salvage all shape what we can learn from this resource.

Keywords: living heritage, Manila Galleons, World War II, Pacific

\section{INTRODUCTION}

The three components of the underwater cultural heritage (UCH) located in the Pacific are a cross section of the temporal and cultural diversity of the $\mathrm{UCH}$ in the region: Living Heritage ${ }^{1}$ and traditional indigenous cultural heritage, the Global Connections of the Spanish Manila Galleon trade, and the legacy of Modern Warfare from World War II (WWII). It draws attention to the very different connections people have had with the sea for 3,500 years ago, from the people who first explored and now live in the region, to those who utilised it for trade, to the toll WWII took on the region, and the material remains left behind.

Across the Pacific, the Federated States of Micronesia (FSM) and Niue in Oceania are the only two countries that have ratified the UNESCO (United Nations Educational, Scientific and Cultural Organization) Convention on the Protection of Underwater Cultural Heritage 2001 (2001 Convention). The 2001 Convention has been established as the best-practice framework for maritime archaeology investigations and management worldwide. Article 1.1.a defines UCH as "all traces of human existence having a cultural, historical or archaeological character which have been partially or totally underwater, periodically or continuously, for at least 100 years" (UNESCO 2001). Its focus is on tangible cultural heritage, and it purposely does not include the term "shipwreck", but uses the broader term "underwater cultural heritage", and therefore should have relevance 
to many of the countries in Oceania. Why has it not been ratified more broadly in Oceania? In comparison, the 16 countries in Oceania ${ }^{2}$ have ratified the Convention for the Safeguarding of the Intangible Cultural Heritage 2003, which highlights the value placed on living heritage in the region. It could be interpreted that FSM and Niue value their UCH as important components of their living heritage, and/or perhaps there were other social-cultural-political reasons for ratifying the 2001 Convention. The dominance of tangible cultural heritage and the dissociation with living heritage in the 2001 Convention could possibly be a hindrance for other countries in Oceania to ratify it.

The aims of the article are twofold: firstly, to introduce three different yet significant themes that help to illustrate the diversity of $\mathrm{UCH}$ in the Pacific; and secondly to consider the value of this $\mathrm{UCH}$, and what direction could be used to facilitate a more integrated approach to understanding, researching and preserving this diverse $\mathrm{UCH}$.

\section{GEOGRAPHICAL AND HUMAN BACKGROUND}

This article focuses on UCH located across the Pacific Ocean, which encompasses parts of Southeast Asia and Oceania (as shown in Figure 1). The Oceania region includes Melanesia, Micronesia and Polynesia. What links all these islands is that they were settled by Austronesian-speaking people. The terms, Melanesia (islands of black people), Micronesia (small islands) and Polynesia (many islands) are European terms that were used to highlight the cultural differences between the inhabitants of the three groups. Regarded by some as a 19th century racist division of Oceania, an alternative terminology that was developed identified "Near Oceania" as comprising New Guinea, the Bismarck Archipelago and the Solomon Islands as far as San Cristobal and Santa Anna (first settled from about 40,000 years ago); and "Remote Oceania" for the rest of the Pacific Islands (which was settled from about 4,000 years ago). This terminology was first delineated in the 1970s, and is now increasingly used (Kirch 2010: 131-133), as it is in this article.

In 1521, the first foreigners moved into the region looking for riches, leading a plethora of Spanish, French, Russian, German, English, Japanese and American explorers, colonialists, missionaries, and traders dominating and manipulating the region and greatly impacting indigenous people. Many indigenous people lost their lives through the introduced diseases; 
in Guam as just one example, the local Chamorro people went from a population of 60,000 to 1,000 in 200 years. Traditional indigenous cultural, languages, trade and exchange systems were greatly impacted, but many have stayed resilient and are still maintained today. After WWII, the islands were divided up amongst foreigner colonial powers. Many achieved independence in the 1980 s to 1990 s, including a free association with former colonial rulers.

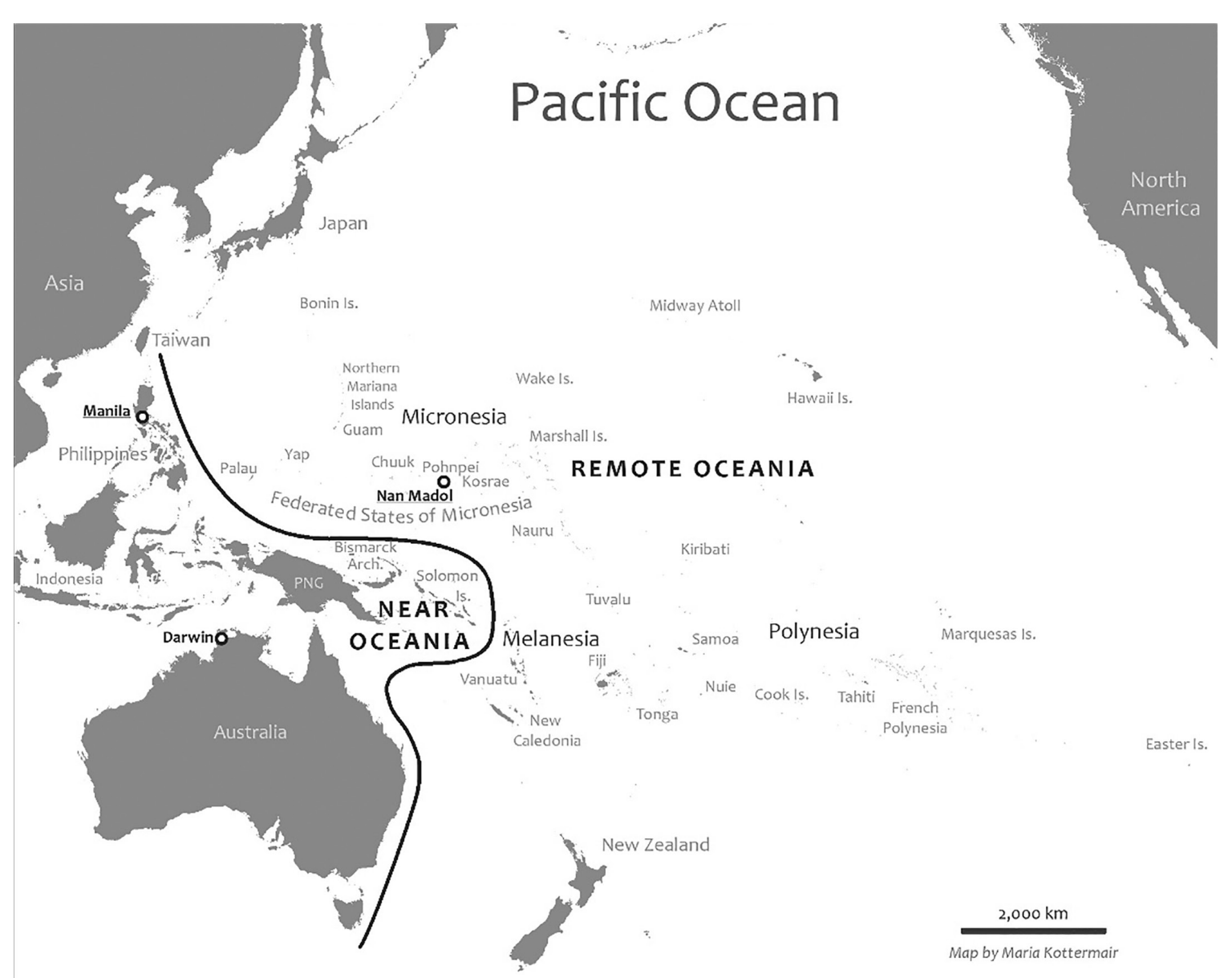

Figure 1: Map of the region showing islands, places and regions mentioned in the article (compiled by Maria Kottermair, 2020).

\section{LIVING HERITAGE: TRADITIONAL INDIGENOUS CULTURAL HERITAGE}

Linguistic anthropological research has shown the Austronesian language family is found from Madagascar in the Indian Ocean, through to and including Southeast Asia and Oceania. The origin of this language, and therefore the origin of the expansion is Taiwan. The stimulus promoted by 
Bellwood (2006: 110) as to why people expanded out of Taiwan included: "a predilection for rapid coastal movement and exploration, probably to find the most favourable environments for cultivation and sheltered inshore fishing, in association with a developing tradition of sailing-canoe construction and navigation". It is also argued by Spriggs (2013: 5) that as people moved out of Near Oceania, where mammals and edible flora were plentiful, and rapidly travelled across Remote Oceania, which contained different and less abundant food, that they had a devastating impact on the pristine environments and caused the extinction of the native fauna in the islands, which led them to further expand across Remote Oceania.

The Marianas Islands were the first islands settled in Remote Oceania at about 3500 Before Present (BP) (Carson 2014: 1). The earliest Lapita people arrived in the region, being the Bismarck Archipelago, its "homeland", about 3350 BP (Spriggs 2013: 1). The Lapita culture is represented by the distinctive incised pottery and other cultural material, including obsidian, stone and shell adzes, arm-rings and beads found in the Bismarck Archipelago in the west and Tonga and Samoa in the east (Clark and Winter 2019: 37). A maritime economy with long-distance exchange commenced in the Sulu and Sulawesi Seas sometime around $4000 \mathrm{BP}$, and led to the Lapita colonisation (Bellwood 2006: 113). Horridge (2006: 144) surmised from other Neolithic boats, that Austronesian-speaking people had a boatbuilding technology comprising of a hollowed base for the hull with added planks, and using lashings, pierced lugs, but with their "own unique triangular sail and the outrigger construction". This information is supported by linguistic evidence (Kirch 2010: 136). From about 2500 BP, they were equipped to make longer sea voyages through the development of the "double canoe", which allowed them to carry more people, food, plants and animals (Horridge 2006: 144). Archaeological evidence found that there is about a 1,000 year pause between the time people arrived in Tonga-Samoa and the movement into the eastern sections of Remote Oceania, with the settling of the furthest islands of Hawai ${ }^{i} i$ (c. 1200 BP), Rapa Nui (c. 1000 BP) and New Zealand (c. 800-700 BP) (Kirch 2010: 140). Austronesian-speaking people moved from the south-eastern Solomon Islands northward into Kiribati, Marshall Islands, then into Kosrae, Pohnpei and Chuuk at about 2000 BP (Yamaguchi, Kayanne and Yamano 2009: 552). Climate fluctuations and "sea-level changes during the later Holocene had a profound influence on the chronology of west-east island colonization" (Dickinson 2003 in Nunn 2007: 33), with sea-level falling and revealing islands at different stages during the period. 
Austronesian people developed unique ways of finding their way, "wayfinding" across the world's largest ocean. This included the use of star compasses, bird observations, cloud formation and colour, and swell patterns as seen in the Marshallese stick chart (as shown in Figure 2). Many exchange systems developed between the islands, which included: Lapita pottery; obsidian in the Bismarcks; food, shells, textiles, navigational knowledge, labour and alliance formation as in the Sawei exchange system in Yap (Hunter-Anderson and Zan 1996: 38-40), and the Kula exchange in and around the Trobriand Islands. "There can be no doubt that the prominence of exchange, in whatever form, is a pervasive and fundamental feature of these Austronesian societies" (Thomas 2006: 304). As Epilu Hau'ofa (1994: 8) stated, "Theirs was a large world in which people and cultures moved and mingled unhindered by boundaries of the kind erected much later by imperial powers". They developed intra and inter island alliances, and a diversity of complex social, cultural and political systems. The coast and sea were places of sacred and spiritual relationships, and together with the intimate knowledge of the marine ecology, they developed a harmonious and sustainable relationship with the marine world. This socio-cultural landscape and seascape reflect the cultural identity of Austronesian-speaking people. Much of this can still be seen today in living heritage. Some can be seen in tangible cultural heritage, such as the traditional indigenous sites found on the islands as well as underwater.

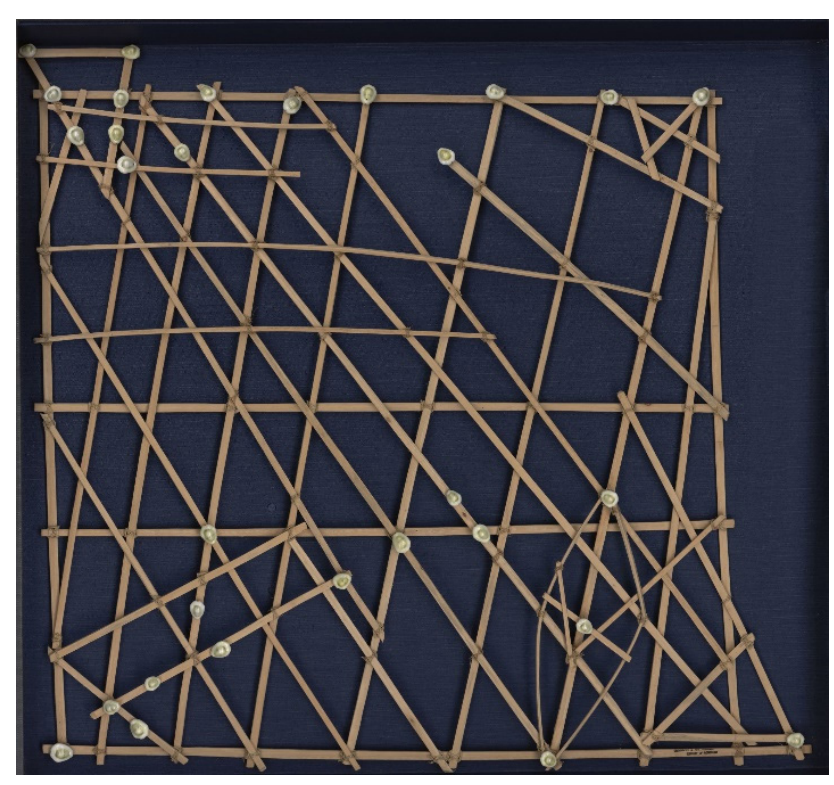

Figure 2: Marshall Islands stick chart, Rebbelib type. Source: Majuro, Marshall Islands: s.n., 192-?; https://www.loc.gov/item/2010586182/. 


\title{
INDIGENOUS UCH THROUGHOUT OCEANIA: CULTURAL PRACTICES, SITES AND OBJECTS
}

At the UNESCO Third Global Strategy Meeting: Identification of World Heritage Properties in the Pacific in Fiji in 1997, the Pacific Island Nations concluded that:

\begin{abstract}
World Heritage sites in the Pacific Islands region are likely to be serial sites and multi-layered cultural landscapes, which attest to the history of voyaging, land and sea routes, and of trade, the first landings, activities, settlements and agriculture in the Pacific Islands region. As serial sites they form lines crossing the boundaries between countries and are therefore transborder and transnational sites. (WHC 1997)
\end{abstract}

A concern of the Pacific Island Nations at a meeting in 1999 was related to the 2001 Convention. They were aware that underwater cultural heritage should be protected. However, they noted "this seems to refer more often to underwater wrecks from World War II, despite the existence of other underwater sites such as sacred cultural sites existing in many areas of the Pacific" (WHC 1999).

However, the canoe, wayfinding and exchange systems are some of the most defining aspects of an Oceania cultural identity related to UCH. Tangible evidence related to early indigenous canoes is rare. In Fiji, remains of a sacred drua (a large double hull sailing canoe that ceased being constructed from about 1883) has been found in swampy ground, where they were intentionally placed for preservation (UNESCO 2010: 45). Today's revival of canoe building and wayfinding by master navigators across Oceania are important in recapturing and maintaining this knowledge, and they provide important cultural and historical contexts for $\mathrm{UCH}$.

Indigenous cultural heritage that can be found on islands throughout Oceania (of which many are coastal features, including some partly submerged) are monumental constructions, house platforms, pathways, money, fish traps, coffins, grinding stones and statues, all made of stone. They include monumental ceremonial, religious and residential architecture that illustrate the shift to hierarchical societies and evidence of the rise of powerful political elites. The largest and most expansive monumental centre is Nan Madol in Pohnpei, FSM (770-750 BP), known as the "Ceremonial Centre of Eastern Micronesia", now a World Heritage Site (NACH 2015) (as shown in Figure 3). A related ceremonial centre is located on Lelu in Kosrae, FSM (c. 640 BP). Nan Madol was built during the Saudeleur 
Dynasty and consists of more than 90 artificial islets built of columnar basalt and coral boulders spread over an area of $1.5 \mathrm{~km} \times 0.8 \mathrm{~km}$ in the intertidal zone adjacent to a small island, Temwen Island, and within the fringing reef of Pohnpei. The islets, separated by navigable channels, became places of residence, administration, ritual and mortuary places for the Saudeleur and their elite. Lelu is a similar megalithic settlement complex built in the intertidal zone within the fringing reef of Kosrae, $550 \mathrm{~km}$ to the southeast of Nan Madol. Oral histories and archaeological remains provide information and evidence on the connection between the two centres, including the ritual kava drinking culture, which is considered to have been introduced into Pohnpei through Eastern Remote Oceanic contacts (NACH 2015: 50-51, 73).

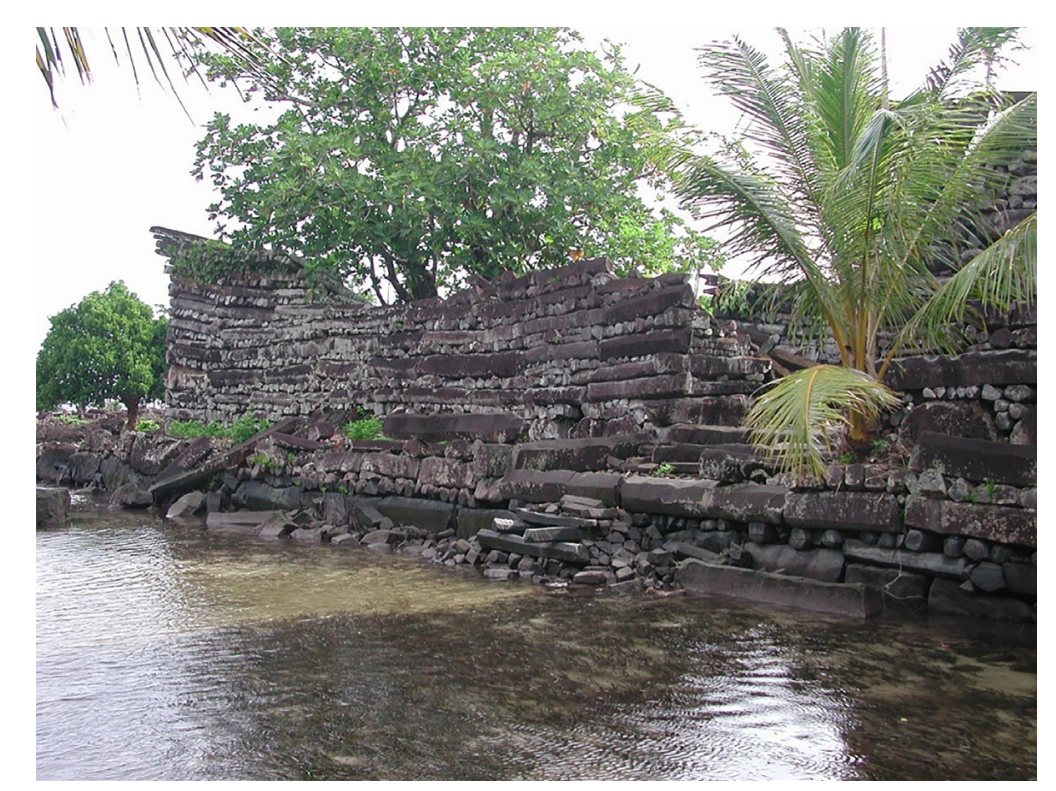

Figure 3: Nandowas Islet, architecturally the most impressive islet at Nan Madol (photo by Bill Jeffery, 2002).

Other cultural remains made of stone found throughout Oceania include: the Latte in the Mariana Islands, many located along the coast (as shown in Figure 4); stone monoliths (some with face-like features) in Palau; the Ahu and Moai in Rapa Nui; the Marae in Eastern Remote Oceania; the Heiau in Hawai' i; mounds used for chiefly ritual performance such as the Samoan star mounds; and the ancient Tongan capital of Mu'a, which contains burial mounds (Langi) and a stone monument called Ha'amonga 'a Mau'i. The "ancient capital of Tonga was the political centre of the Tongan Maritime Empire, which dominated a vast region that included parts of Fiji and Samoa, and was ruled by the Tu'i Tonga [Royal Family] from AD 1200 
to AD 1800" (NACH 2015: 61-71). While the Kingdom of Tonga is large enough to be considered an emerging state-level centre, Nan Madol is the most expansive and outstanding example throughout the whole of Oceania (NACH 2015: 71). Other major settlement sites can be found throughout Oceania, including ancient timber village remains located in swampy ground on the island of Huahine, Society Islands and French Polynesia, as well as submerged timber pillars for a Maneaba (indigenous meeting place) on Nonouti Island in Kiribati (UNESCO 2010: 48, 54).

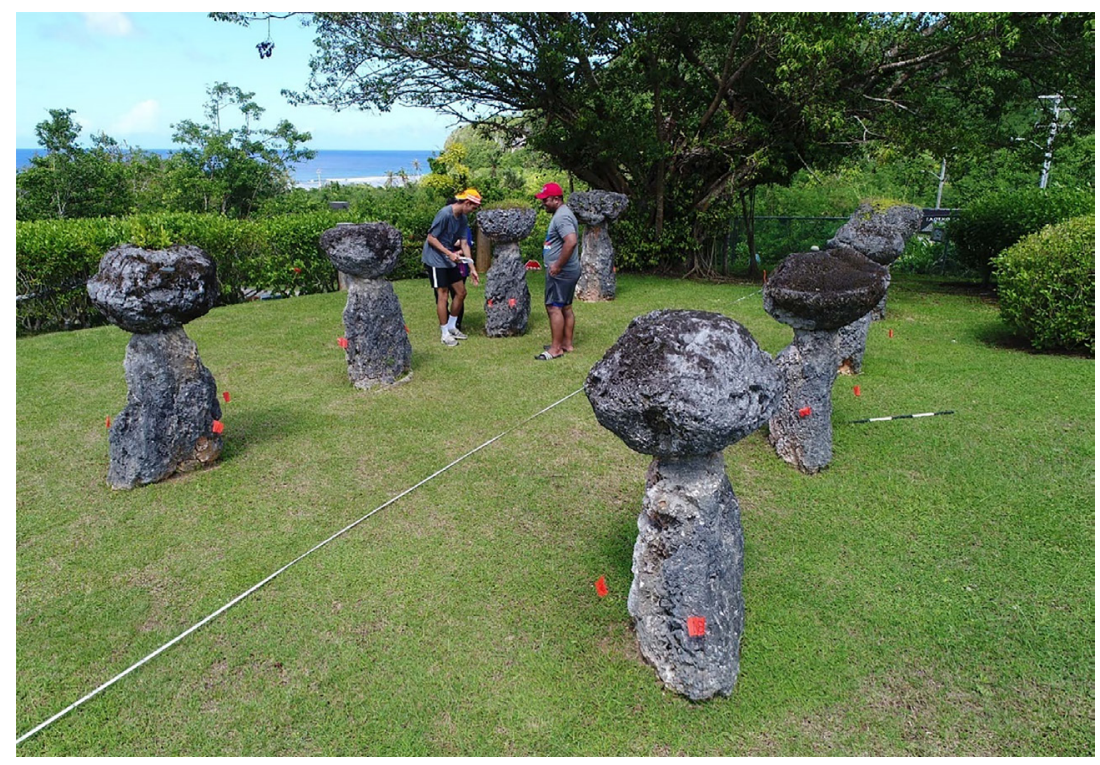

Figure 4: Reconstructed Latte set in Guam being surveyed by University of Guam students (photo by Bill Jeffery, 2018).

In Yap, stone money (rai) was quarried in Palau and transported initially by a combination of canoe and raft, and later by larger foreign ships to Yap from about 600 BP until the 1930s. In 1929, 13,281 rai were located in Yap (Gillilland 1975: 11). The white aragonitic limestone of Palau was a highly prized stone for carving the disks, and which are still used today in a number of transactions. The rai are considered "the largest objects ever transported over open ocean by Pacific Islanders [prior to foreign contact]" (Fitzpatrick 2009: 94). A number of oral histories relate to canoes disappearing on the voyage back to Yap, but the rai are still remembered and valued today by the original owners' descendants. The other important material type that was widely distributed throughout Oceania in exchange systems, and even used as "money", were shells - from the large worked tridacna, trochus fish hooks, cowrie and pearl shell, and including those made into rings, beads and pendants (Kirch 1987: 174-178). 
Another extensive stone material culture related to indigenous people that can be found underwater and spread across the Pacific are the tidal stone-walled fish weirs, also called fish traps. Built of basalt on the high volcanic islands, they are also located on low-lying coralline islands utilising limestone rocks, where a reef flat allows for their use. "Fish weirs" rely on the falling tide to trap fish behind a stone-walled enclosure, whereas "fish traps" are constructed in a way to guide fish into a trap, such as in the Yapese aech (Jeffery 2013) (as shown in Figure 5). Fish traps can also refer to a small basket enclosure made of bamboo, used in association with a weir/trap or on its own to catch fish. But it is the stone weir/trap, and the many other devices built of stone by indigenous people that predominantly survive hundreds or thousands of years that highlight the traditional ecological knowledge developed in association with the spiritual and harmonious interaction people had, and still have, with the marine environment. This interaction and knowledge could help contemporary societies in their marine conservation efforts in an age where fish stocks are being greatly depleted (Gilbert 2016: 221).

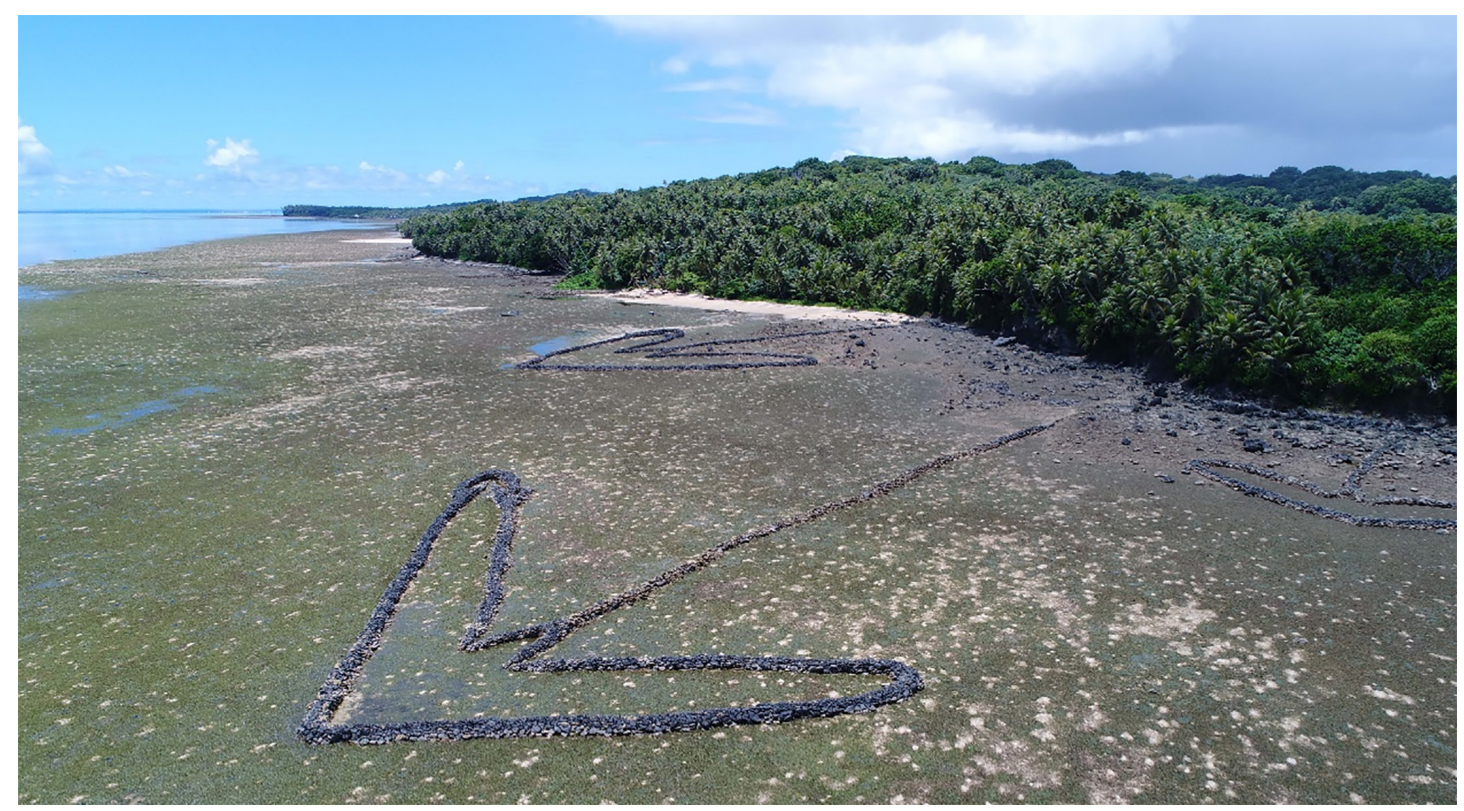

Figure 5: Yapese fish trap (aech) located in the village of Rikeen (photo by Bill Jeffery, 2018).

A range of smaller material culture related to indigenous people can be found throughout Oceania and located underwater. Examples include: a collection comprising 4,288 Lapita pottery sherds and stone adzes from about 3000 BP at Muifanua, Upolu, Samoa (UNESCO 2010: 85), and a 
prehistoric site located underwater off Fefan in Chuuk, FSM, in which pottery dates from 2350 BP to 1650 BP (Rainbird 2004: 89). In Guam, many thousands of slingstones have been found on the island (Craib 1986: 137, 219, 234-236), and a number of small caches have been found underwater and considered to be the result of warfare between Chamorro groups. Slingstones are small-pointed rocks $(3 \mathrm{~cm}$ to $10 \mathrm{~cm}$ long) made of limestone, fine-grained basalt, or even baked clay. Used as weapons and in hunting, they can be found across Oceania (York and York 2011). A smaller number of grooved slingstone-shaped stones, similar to contemporary fishing-net weights made of baked-clay have been found on Guam (Craib 1986: 219-220). About 2,000 to 3,000 artefacts including unworked and worked basalt artefacts related to fishing (anchors and net weights), and a smaller number of basalt adzes and a pestle were found underwater and spread over an area of 1.5 hectares near Tupaparau Pass in Moorea, French Polynesia. Guérout and Veccella (2006: 95) suggested "some stones may have come from ceremonial sites such as Marae [a sacred place]".

There are many sacred and spiritual associations with natural heritage located underwater across Oceania. For example, particular sea locations in the Solomon Islands can be used for shark, whale and crocodile calling (UNESCO 2010: 89). In Chuuk, FSM, a section of a submerged reef can be marked as a sign of respect and mourning to a deceased chief and access prohibited. Burials can take place at sea, such as in Chuuk, and on Bike islet, Kiribati, which was used as a cemetery and is now submerged. On Niue, there are submerged funeral caves, which are an important part of their cosmology (UNESCO 2010: 53, 69). Inundated caves can be found across Oceania and have the potential to contain evidence of indigenous use. In Guam, there are hundreds of caves, and some coastal caves intersect the freshwater lens, making them ideal places for habitation, with many containing pictographs, and adjacent burials. During WWII, caves were extensively used as refuges, churches and hospitals by Chamorro people (Taboroši and Jenson 2002).

This section has concentrated on traditional indigenous cultural heritage, which can reflect aspects of an indigenous cultural identity. Traditional indigenous cultural material can also be found in EuroAmerican shipwrecks, of which there are several. They include HMS Pandora (1791), the British vessel that searched for the mutineers of HMS Bounty and was subsequently wrecked off the north-east coast of Australia. During the three months of searching, the crew collected hundreds of objects (including stone and shell adzes, clubs, pounders, fish hooks, lures and a Tahitian mourning gown) from Tahiti, Tokelau, Samoa, Tonga and 
Rotuma, which went down with the ship; many were however recovered from 1977-1999 (Campbell and Gesner 2000: 125-135). In 1874, the German vessel Alfred was wrecked off Jaluit in the Marshall Islands carrying ethnographic and biological material from parts of Oceania. It was a collection gathered together by Johann S. Kubary for the Hamburg Trading Co. Godeffroy \& Son Museum. Kubary visited Solomon Islands, New Britain, Samoa, Ebon, Yap, Palau, Jaluit, Chuuk and Pohnpei (including Nan Madol) and packed his collection into 100 crates that were aboard Alfred. "The treasures of 'The Royal Tombs' [assumed to be Nan Madol] went to the bottom of the sea" (Lawson 2018: 2-5).

In Oceania, certain countries and territories such as in the Mariana Islands, FSM, Marshall Islands, Fiji, French Polynesia have implemented maritime archaeology activities but in a piecemeal manner. In the United States of America (US), affiliated nations such as the FSM and Marshall Islands, and the government-funded Historic Preservation Offices (HPO) in association with the US National Park Service (NPS), have implemented implement mainly terrestrial-based programmes but are starting to investigate and manage $\mathrm{UCH}$; the FSM recently advertised for an archaeologist, preferably with maritime archeology expertise. In 2016, the University of Guam implemented an ethnoarchaeology field school in Yap, focusing on the Yapese canoes, stone money and fish weirs. Together with the six other field schools implemented in Guam and Chuuk from 2009 to 2017, the capacity building of local people has been a priority. It is hoped this will empower the local community to initiate and conduct community maritime archaeology projects under the direction of indigenous maritime archaeologists, supported by the HPO, and in association with other groups in maintaining and reviving living heritage.

\section{GLOBAL CONNECTIONS: SPANISH MANILA GALLEON TRADE IN THE PACIFIC}

By the 16th century, Spain had established a foothold in the Atlantic Ocean and the Americas and were looking to expand west into the Pacific Ocean. At the same time Spain was establishing the Atlantic trade, there was a burgeoning trade in Asia and Southeast Asia between China, the Philippines, India, Japan and other areas of the region (Min 2013; Giráldez 2015; Lyon 1990). In an effort to take advantage of that trade, Spain began expansion into the Pacific, sending explorers to the region with varying degrees of 
success. Ferdinand Magellan reached the spice islands of Moluccas and the Mariana Islands in 1521, the same year a base in Acapulco, Mexico, was established and called New Spain (Pigafetta 1969; Peterson 2014). More explorers set out to establish a trade route between Asia and the Americas, and by 1565, Miguel Lopez de Legazpi and Andres de Urdaneta claimed many of the islands of the Pacific for Spain including the Philippines and the Mariana Islands. This laid the groundwork for a route between Manila and Acapulco and officially established the Manila Galleon trade, and eventually added another layer of underwater cultural heritage to the region (Rogers 1995; De Leon-Bolinao 2014).

Manila provided enough resources to support the Asian-based centre Spain needed to begin the trade, including the materials for construction of galleons, an established working port, and an existing trade centre. Spain also capitalised on indigenous peoples' labour and resources such as their knowledge of the region's waters, the best resources and techniques for constructing ships, and their ability to sail and navigate (Peterson 2014). Soon products of the region including textiles such as silks, precious metals, cotton, tea, opium, porcelains and other ceramics, and spices were moving east towards the Americas and eventually Spain (Giráldez 2015).

Galleons facilitated the trade, departing Manila in June, travelling through the Philippine islands into the Pacific by August or September, heading north to catch the Kuroshio current that took them east toward the west coast of the Americas, and traveling south until such time they arrived at Acapulco between December and February (Buschmann, Tueller and Slack 2014; Angaro and Madrid 2017) (as shown in Figure 6). Galleon arrivals in Acapulco created much excitement as merchandise from Asia was highly sought after, and supplemented a shortage of desired products in the region (Fish 2011; Schurz 1939).

The process to return began soon after the cargos were unloaded and the trade fair was over. Passengers and goods from Europe and the Americas were loaded onto the ships including government officials, clergy, merchants, military personnel as well as corn, sugar, olives, soap, livestock, leather, furniture, cocoa, chili, clothing, cutlery, minerals, iron and silver to pay for the goods in Acapulco and subsidise the colony (Fish 2011; Quimby 2012; Driver 1993). From 1565 to 1815,400 voyages between the Manila and Acapulco were recorded (Isorena 2015).

The Manila-Acapulco Galleon trade network eventually dissolved in the early 19th century due to competition and restrictions in trade and Spain's loss of control over colonies. Nevertheless, the network created a new global 
network, engaging Europe, the Americas, the Pacific and Asia in a longdistance lucrative, but dangerous venture, as evinced by the shipwrecked galleons found in the region.

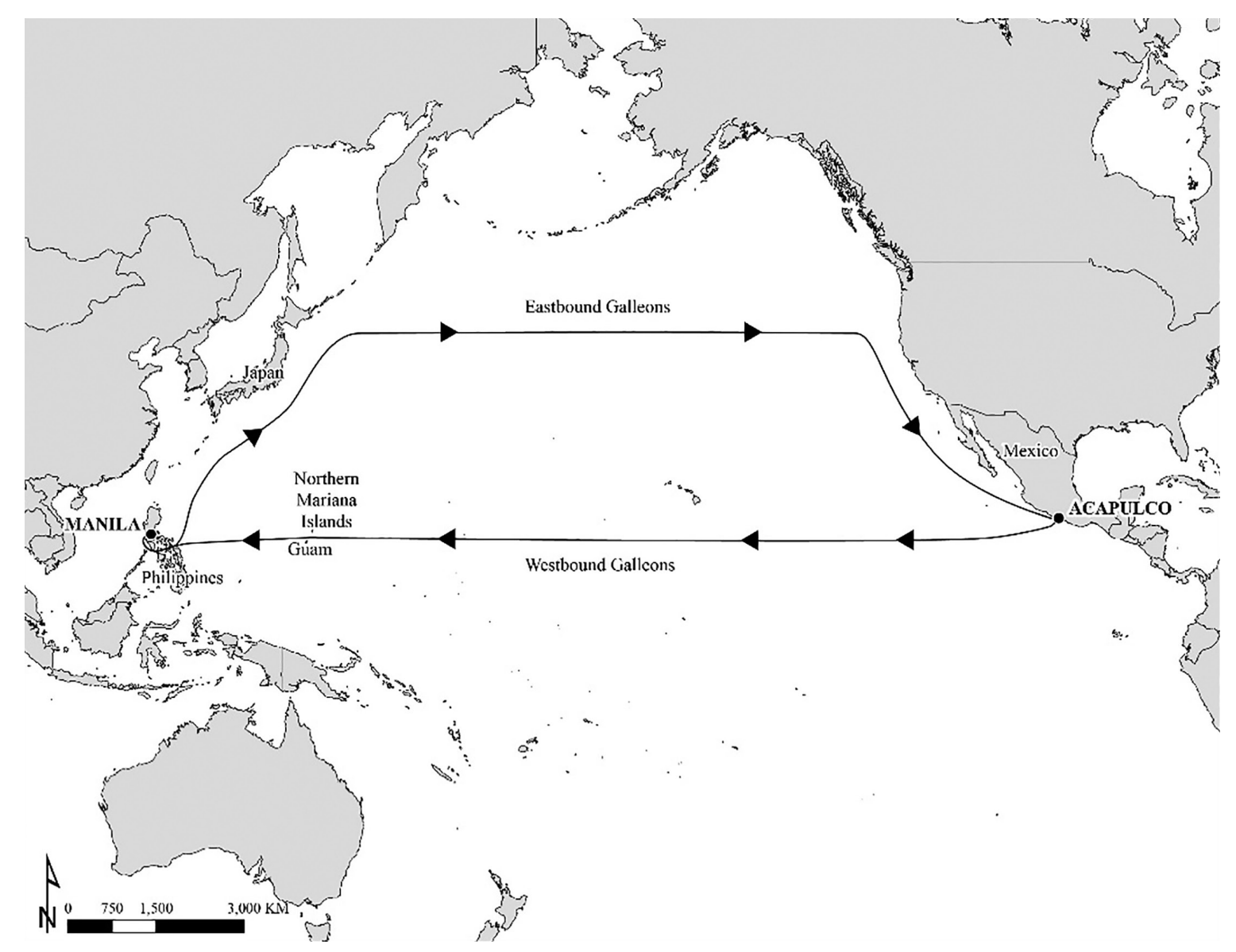

Figure 6: Manila Galleon trade map (image courtesy of Aleck Tan).

\section{MANILA GALLEONS: SHIPWRECK PROJECTS}

While there is an abundance of foreshore and terrestrial site types related to the Manila Galleon trade in Asia Pacific, UCH site types comprise mostly the shipwrecked galleons that popularised the trade. A total of 59 known shipwrecks occurred and of these only a handful have been investigated (Isorena 2015; Junco 2011). Below is a brief description of those shipwreck projects.

Within the Mariana Islands, three shipwrecks have been located and investigated to varying degrees by for-profit treasure hunting ventures (McKinnon and Raupp 2011; McKinnon 2017; Tan 2020). Santa Margarita wrecked in 1601 off the coast of Rota with a crew of over 300 people, 
of which only a handful survived (Driver 1983; Trusted 2013). The site was contemporaneously salvaged by both the indigenous Chamorro people and the Spanish. IOTA partners, a Seattle-based company, received a permit to salvage the remains and conducted work on the shipwreck from 1994 to 2006 before they violated environmental permits and their operation was shuttered. Objects recovered include ceramics, beads, precious stone, an anchor, copper ingots, clavos, timber fragments, ballast stones and ivory. Nuestra Señora de la Concepción wrecked in 1638 off the coast of Saipan with only a handful of survivors. This site was also salvaged by both the Chamorro people and the Spanish. A company called Pacific Sea Resources received a permit to salvage the shipwreck in the late 1980s (Mathers 1990; Mathers et al. 1990; Mathers and Shaw 1993). Others have attempted salvage of the site and nearby beaches including Doug Ranking, IOTA, and Proa (Tan 2020). Objects recovered included jewelry, storage jars and ceramic sherds, an anchor, glass beads, lead and iron shot, lead sheathing, furniture fittings, porcelain, cannon parts, hemp, resin and personal items (Mathers et al. 1990). Nuestra Señora del Pilar de Zaragosa y Santiago wrecked of the coast of Guam in 1690 with a crew of 185, all of which were reported saved. Because it sank at depth, the entire cargo went down with the ship. A company called Pilar Project Ltd., received a permit from the government to salvage the site beginning work in 1991 (Richardson 2001). Artefacts reportedly recovered from the site include weaponry, coins, timbers and fasteners, ceramics and ballast stones.

Three shipwrecks have been located and investigated by archaeologists on the US mainland. San Agustín wrecked in 1595 in Drakes Bay, California. Artefacts from the shipwreck were excavated in Native American sites within the bay area in the 1940s, and in the late 1980s, the NPS undertook a survey to locate the wreck (Murphy 1984). Ceramics and other artefacts washed ashore have been studied to help identify the wreck as San Agustín. Further to the north off Oregon is a shipwreck known colloquially as the Beeswax Wreck due to the cargo of beeswax that periodically washes ashore. The likely candidate for the shipwreck is Santo Cristo de Burgos (1693), the fate of which little is known as it was reported to have just disappeared in the Pacific. A local group of archaeologists have been investigating this shipwreck for a number of years and oral histories from Native American groups in the area suggest they are descendants of the sailors (Williams 2014, 2018; Lally 2016; Peterson et al. 2011). To the south in Baja California, a shipwreck has been investigated for nearly two decades by US researchers and the Instituto Nacional 
de Antropología e Historia in Mexico. The location of the shipwreck is unknown; however, ceramics and other materials have washed ashore and been studied (Junco 2011, 2016). A likely candidate based on ceramic analysis is San Juanillo which wrecked in 1578 and was lost without a trace (Von der Porten 2019).

Of the 59 shipwrecks known, 41 are reportedly located in the Philippines, but only a handful have been investigated; there are however several attempts at finding others (Sheldon and Orillaneda 2019). The site that has received the most investigation with results is that of San Diego, which sank in 1600 near Manila during a battle with the Dutch (Isorena 2015; L'Hour 1994). Built in Cebu, the ship shares traits with other galleons built at the time; however, its function was a warship at the time of its sinking and so it is questionable whether it can be considered a Manila Galleon. San Diego was located by Franck Goddio of the Far Eastern Foundation for Nautical Archaeology and was investigated in partnership with archaeologists from the National Museum of the Philippines in 19911993 (Goddio 1994). Thousands of ceramic fragments, whole storage jars, weaponry, religious items, navigational devices, precious metals and coins, cannon, anchors and other artefacts were recovered. Other shipwrecks have been the subject of limited investigations, including Nuestra Señora de la Vida (1620) off Verde Island, Encarnacion (1649) off Sorsogon, San Jose (1694) off Lubang Island, Santo Cristo de Burgos (1726) near Sorsogon and Masbate, and San Andres (1798) near the entrance of Embocadero (Sheldon and Orillaneda 2019).

Shipwrecked galleons are the most obvious and certainly most popularised representative UCH site type of the Manila Galleon trade; however, there are more sites to consider underwater and in the foreshore areas. UCH sites that can add to our knowledge about the Galleon trade include underwater features of ship construction sites, landing and port sites, careening sites, grounding sites, salvage response sites, support vessels and other ancillary sites. Focusing on shipwrecks alone limits understanding of this important trade network; hence work should also be conducted in conjunction with foreshore and terrestrial related sites $(\mathrm{Wu}$, Juncho and Sanchez 2019). Additionally, consideration for a multi-vocal approach would include areas of research that are particularly understudied including the contemporary relevance of, for example, the indigenous peoples' contributions, coerced or otherwise, to the trade and their subsequent salvage and use of shipwrecked materials. 
Unfortunately, the lure of treasure and riches continues to attract for-profit treasure hunting individuals and corporations that prey upon the economic needs of the region while lining their pockets with investment monies in search of the ever-elusive Spanish galleon (Throckmorton 1998). This removes the heritage and benefits from the local community. More work needs to be undertaken as only a few galleons have been located, identified and scientifically investigated by archaeologists. Projects such as the recent search for San Francisco (1609) in Japan are expanding that research into other areas of the Asia-Pacific region (Kimura 2019). Nevertheless, more research on these sites within the context of their maritime cultural landscape and seascape is much needed.

\section{MODERN WARFARE: THE LEGACY OF WWII IN THE PACIFIC}

Commensurate with the scale and complexity of the conflict, WWII left a widespread cultural footprint across the Asia-Pacific region. The historical consequences of the war, the sacrifices of combatants and non-combatants alike, and continuing environmental impacts heighten concern for this resource. The brief summary below includes some (certainly not all) $\mathrm{UCH}$ surveys and issues.

Expansion and national competition for oil and minerals set the stage for conflict between the Allied powers and the Empire of Japan. Prior to the outbreak of war, Japan militarised locations in the Pacific. Meanwhile the US military prepared the Territory of Hawai $i$ to be a major supply/ repair base, the springboard for the American Fleet. Following the attack on O'ahu's military installations on 7 December 1941, Japan's forces quickly expanded throughout the Western Pacific and Southeast Asia. Initial advances were staggering, but Japan could not sustain the production necessary for a war of attrition. Advances halted at the Battle of Midway and at Guadalcanal by mid-1942, and from then until the war's end, the Allies' amphibious campaign swept westward across Central and South Pacific waters, pushing Japan's forces back towards the home islands. The US lost an estimated 774 naval ships in WWII (Neyland 2017). During the war, over 7,000 Japanese vessels sank, including some 500 warships, 2,500 freighters and 4,000 small vessels under 100 tons (Iwabuchi 2017). Aircraft were lost in the tens of thousands. The true cost and tragedy, though, are measured in human lives. Including military and civilian deaths, casualties in the Pacific War numbered around 36 million or $50 \%$ of the total casualties of WWII (Budge 2016). 
Today, war-related UCH remains as the physical shadow of this conflict. The location and character of the UCH resources and remains in the Pacific reflect the strategies of the war campaigns as well as the innovations in WWII tactics and technology, and include the following.

\section{Capital Ships}

Investigation of capital ships often requires long-term support or deep ocean survey capability. The US NPS initiated a survey of the battleship USS Arizona (as shown in Figure 7) and the former battleship USS Utah at Pearl Harbor in the 1980s (Lenihan 1989). Research on site formation processes and the deterioration of these ships is ongoing (Wilson et al. 2007). In the 1990s, oceanographer Robert Ballard and National Geographic surveyed Guadalcanal's Iron Bottom Sound, and located USS Yorktown, sunk during the Battle of Midway in June 1942.

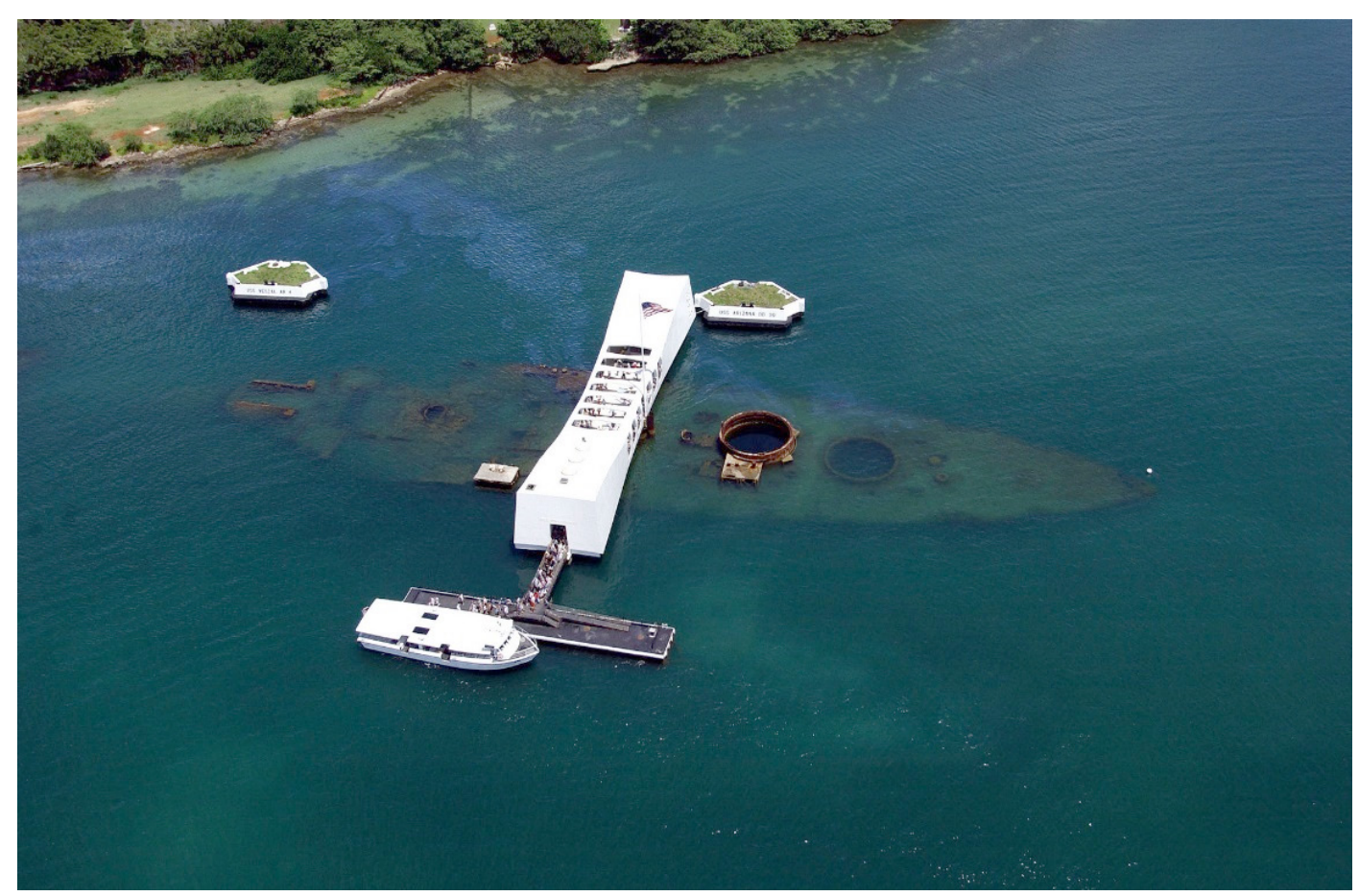

Figure 7: Aerial view of the USS Arizona at Pearl Harbor, Hawai $i$, with a visible surface sheen of fuel oil (image courtesy of US Navy). 
The great interest in frontline capital ships has captivated entrepreneurs as well. In 1986, Paul Allen (co-founder of Microsoft) launched the company Vulcan Inc., dedicated to, among other tasks, finding WWII shipwrecks. To date, Vulcan Inc. has located and documented: USS Vincennes and Astoria, Japanese battleship Musashi (2015); USS Indianapolis and Ward, Japanese battleship Fuso, IJN Yamashiro, Yamagumo, Michishio and Asagumo (2017); USS Lexington, Juneau and Helena (2018); USS Hornet, Johnston, Wasp, and Japanese carriers Kaga and Akagi (2019). These surveys do not always generate publicly accessible information, but private self-funded entities are not responsible for public preservation. Vulcan Inc.'s intentions are to locate historic shipwrecks; hence limited information is shared in a press release format. The bulk of the data remains proprietary. Unfortunately, this does little to advance subsequent preservation or management objectives for UCH resources.

\section{Amphibious Vessels}

The Pacific campaign required that heavily defended islands be captured, necessitating landing armed forces ashore. Allied forces conducted 78 Pacific landings during the war. Amphibious landings demanded greater coordination of air, sea and ground forces than ever before, employing improved tactics and innovative landing ships, landing craft and amphibious assault vehicles (AMTRACS). In 2010, East Carolina University teamed with Ships of Exploration and Discovery Research to survey the landing areas for the battle for Saipan (McKinnon and Carrell 2015). The University of Guam's field school also featured amphibious-related projects such as "Seabee Junkyard" in Apra Harbor and the AMTRAC survey at Agat (Applegate-Palmer and Jeffery 2014). Surveys focused on smaller craft are often well suited to academic field training (as shown in Figure 8). For several years, the National Oceanographic and Atmospheric Administration (NOAA) with the University of Hawai i (UH) have supported field surveys investigating the amphibious training beaches in Hawai $i$ (Van Tilburg 2014). Scuttled amphibious vessels have also been found in the deep ocean by the Hawai' i Undersea Research Lab or HURL (Van Tilburg and Delgado 2017). 


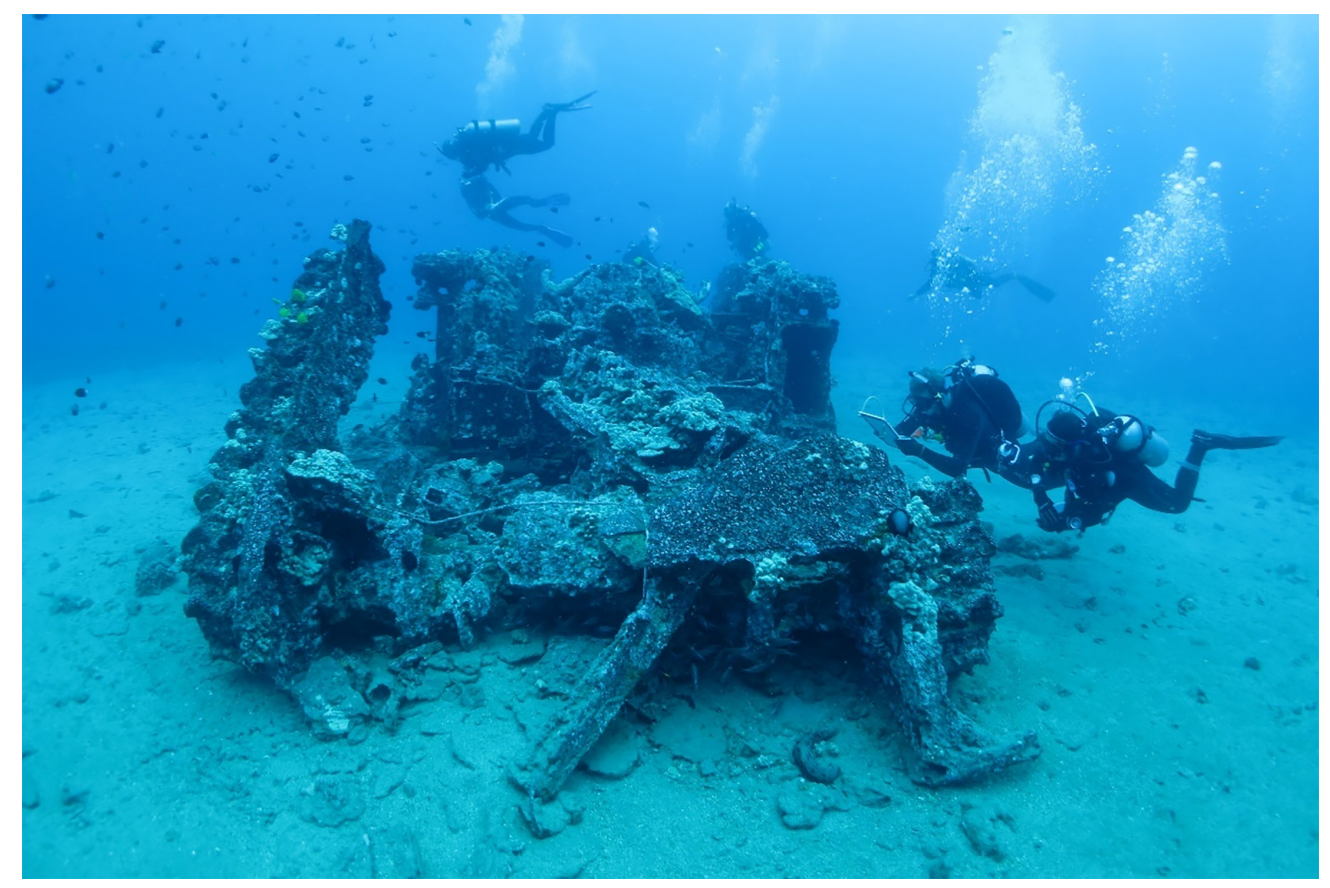

Figure 8: UH students recording an AMTRAC site (LVTA-4) lost during training exercises in 1944 (photo courtesy of NOAA ONMS).

\section{Aviation Resources}

The outbreak of WWII demonstrated the effectiveness of naval aviation. When found in situ, submerged archaeological evidence can render technical, combat and loss information. In 2016, a B-29 was documented by NOAA's Oceanos Explorer, adding to the study of the mass bombing campaign launched from the Marianas Islands (Lickliter-Mundon et al. 2018). Indonesia's Ministry of Education and Culture has also surveyed a P-38 Lightning (Andriany 2017). Archaeologists have also documented 15 PBY Catalina flying boats in Darwin Harbor, Australia (Jung 2001). Two rare TBD Devastator torpedo bombers have been recorded in Jaluit Atoll, Marshall Islands by the Naval History and Heritage Command (NHHC) and The International Group for Historic Aircraft Recovery. Combat and training operations in Hawai $i$ during the war left a resource of some 1,250 WWII naval aircraft in island waters, many of which have been surveyed by the NOAA/UH field courses and HURL's manned submersibles (Rodgers, Coble and Van Tilburg 1998; Van Tilburg and Delgado 2017). Many other aircraft have been documented at former battle sites such as Chuuk Lagoon and Palau. Organisations like Bentprop and Project Recover, working in coordination with the US Defense POW/MIA Accounting Agency, are groups committed to locating and documenting these aviation losses. 


\section{Submarines}

Beginning in 1900, submarines began to evolve from small coastal defense boats to the large ocean-going fleet boats of WWII. UCH surveys can shed light on loss events previously shrouded in silence. Similar to capital ships, avocational groups have taken to the search, locating 9 of the 52 lost US submarines, including USS Wahoo, Legarto, Robalo, Flier and USS Perch (see "Ownership and Salvage"). Between 2017 and 2019, entrepreneur Tim Taylor documented USS S-26 off of Panama, USS S-28 off of $\mathrm{O}^{\circ}$ ahu (lost during torpedo training), USS Grunion's bow in Alaska, and USS Grayback offshore of Okinawa. Additional resources are also available from the USS Bowfin Submarine Museum in Honolulu, but (as mentioned earlier) private entities are not obligated to pursue preservation goals; the bulk of site information often remains proprietary and unavailable to the public. HURL, NOAA and the NPS collaborated in studying two of the five Japanese midget subs lost during the Pearl Harbor attack (as shown in Figure 9), initiated by HURL's 2002 discovery (Delgado et al. 2016). A similar version of this submarine was found near Sydney, Australia in 2006, Australia's Heritage Office completing an extensive report for management purposes (Smith 2007). HURL and NOAA later continued their collaboration following HURL's survey of the Japanese aircraft-carrier submarines I-400, I-401, I-14, and fast attack submarine I-201, all of which were captured at the end of the war and intentionally sunk in 1946.

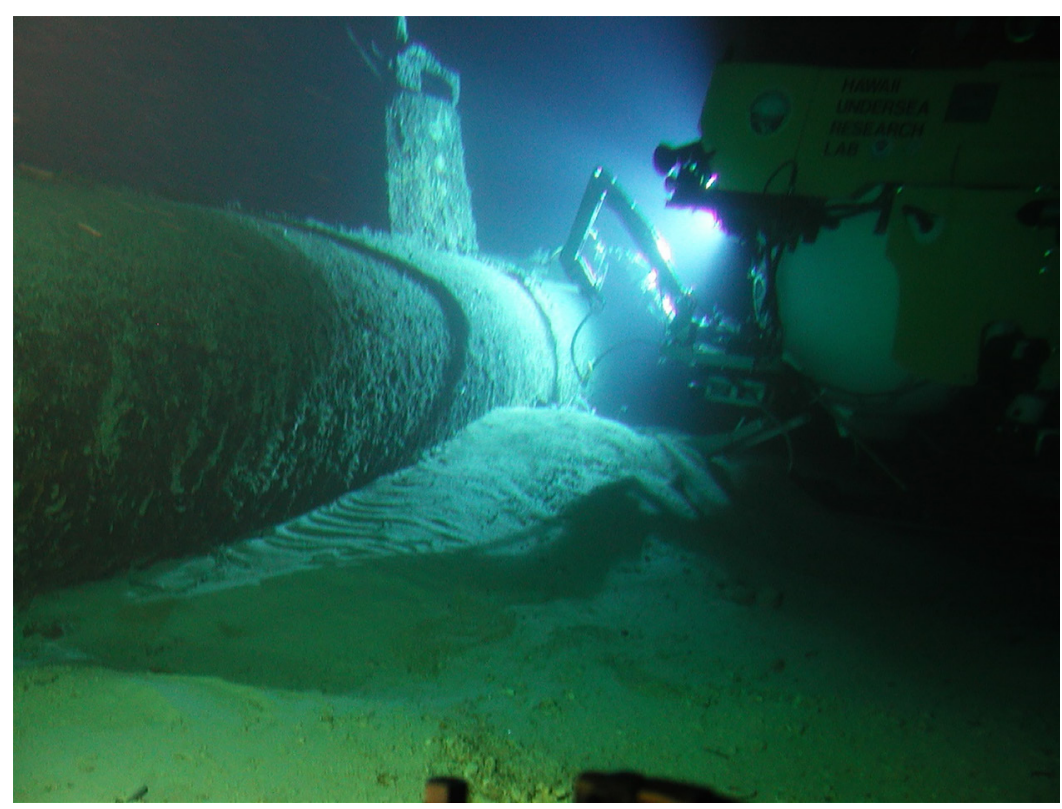

Figure 9: HURL submersible conducting survey of the Japanese two-man midget submarine sunk outside the entrance to Pearl Harbor (photo courtesy of HURL). 


\section{Auxiliaries}

Auxiliary vessels provide critical support for replenishment, transport, repair, rescue and other roles; their numbers and losses far outmatch the combat vessels that usually garner greater attention. The Vanuatu Cultural Center has placed the wreck of SS President Coolidge, converted into a troop transport and sunk by a mine in 1942, on its Tentative List for the Vanuatu Heritage Site (Willie and Shing 2017). NOAA's 2003 surveys at Midway Atoll included USS Macaw, a submarine salvage and rescue vessel lost during an attempt to pull USS Flier from the reef in 1944. The Japanese auxiliary Amakasu Maru (as shown in Figure 10) was actually surveyed during a NOAA investigation of a sonar target believed to be the Japanese destroyer Hayate, lost during the Battle for Wake Island in 1941 (Cantelas et al. 2017). And James Cook University scientists believe they have located the wreck of USS Neosho, a fleet oiler now resting almost $3 \mathrm{~km}$ deep. Auxiliaries are often found near locations of intense conflict and losses, such as Palau, Guam and Chuuk Lagoon. Like combat vessels, many of these shipwrecks are popular tourists dive spots.

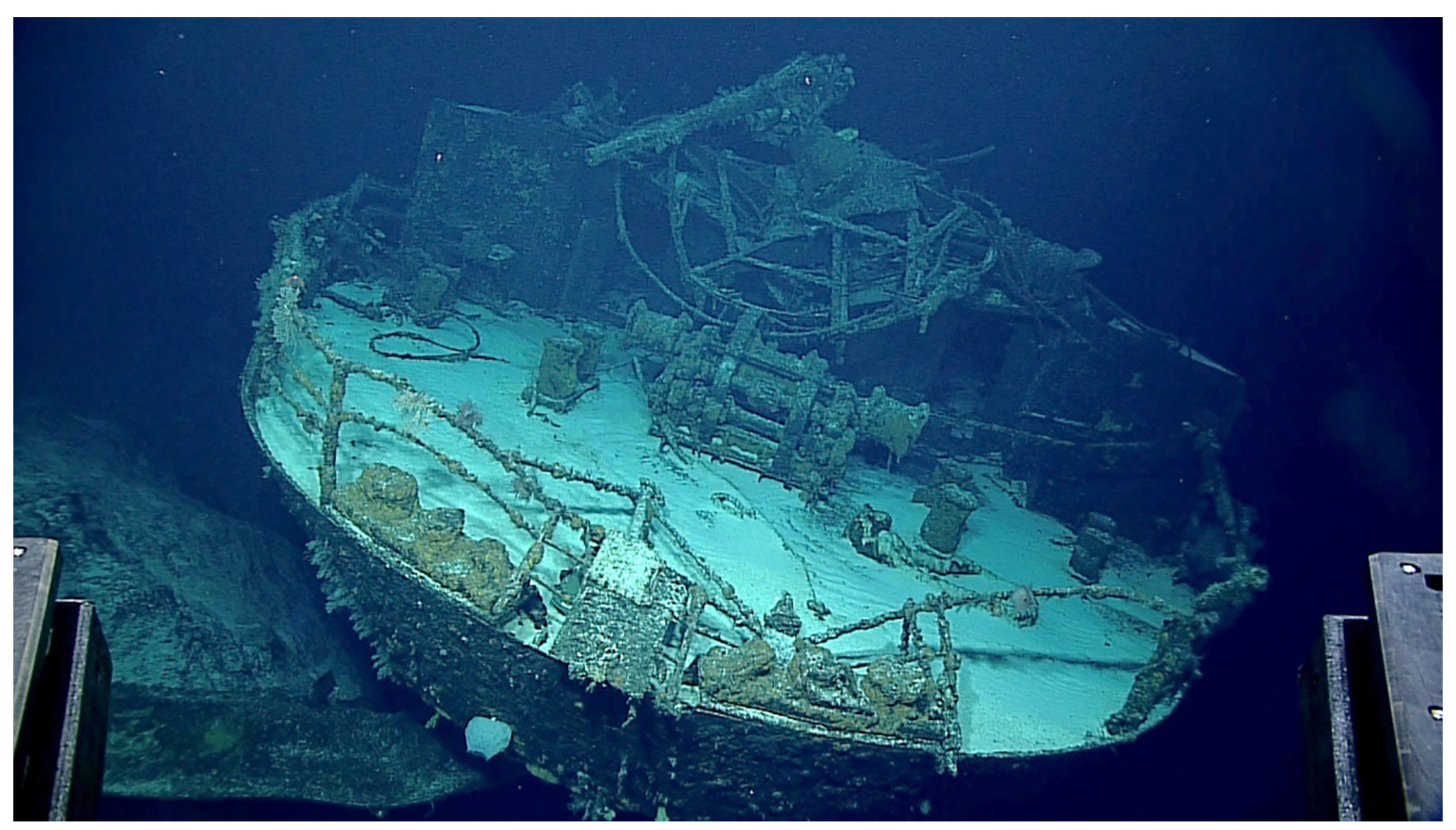

Figure 10: Stern of the Amakasu Maru No. 1, a naval auxiliary, sunk in 1942 near Wake Island (photo courtesy of NOAA OER). 


\section{WWII UCH LANDSCAPE IN THE PACIFIC}

World War II UCH resources exist in all marine environments, from the surf zone to the oceanic abyss. They can include shoreline defensive infrastructure. In American Samoa, an inventory of coastal fortifications has been completed, including now-submerged shoreline pillboxes (Kennedy 2005). WWII vessels were sunk during combat; damaged and lost later while transiting; accidentally grounded during normal operations or training activities; or intentionally abandoned or scuttled or used as target assets. In all these losses, there is an element of patterned distribution that describes a portion of human military behaviour.

The environment influences military strategy and tactics, which in turn shape the archaeological record of the battle. The interpretation of submerged battlefields advances this approach by modifying components of terrestrial battlefield interpretation for the marine environment (Babits et al. 2011; Roth and McKinnon 2018). Aspects of key terrain, observation and fields of fire, cover and concealment, obstacles, and avenues of approach and withdrawal find counterparts in the marine environment, illuminating tactical and strategic decisions. Sheltered locations that served as anchorages, are known for concentrations of WWII wrecks: Chuuk Lagoon has more than 50 submerged sites (Jeffery 2017); Palau has more than 40 sunken ships (UNESCO 2017); Guam has 118 UCH sites (Jeffery and Moran 2007) and others. Following the cessation of hostilities, though, the interpretation of former combat sites takes on further aspects as outlined below, including memorialisation, economic value and threats to the ecosystem.

\section{Heritage, Tourism and Gravesites}

The memory of WWII has opened opportunities for diving and heritage tourism in many locations. Today the majority of tourism in the FSM is based on WWII heritage tourism, supporting a multi-million-dollar diving industry. There are more than 60 WWII ship and aircraft wrecks sites in Palau, many being popular destinations for recreational divers. For the $\mathrm{UCH}$ benefits of visitation to be maintained, protocols must be established for responsible and sustainable (zero impact) access. Many WWII UCH wrecks are gravesites for war dead. There are still 300,000 human remains of Japanese soldiers and sailors under the sea (Iwabuchi 2017). The sensitive issue of war dead highlights the need for international cooperation in this field. In 2017, UNESCO published Safeguarding Underwater Cultural 
Heritage in the Pacific, specifically addressing preservation issues such as the treatment of human remains and guidance for accessing WWII UCH sites (UNESCO 2017).

\section{Ownership and Salvage}

Despite increasing preservation awareness, looting can threaten WWII UCH sites. Military craft from certain nations are protected as state/sovereign craft by national legislation no matter their location (e.g., Sunken Military Craft Act for US vessels). Nonetheless, illegal salvage impacts the UCH resource on both small and large scales. Salvage firms are reportedly cutting apart and raising WWII wrecks to recover metals, including highly sought low-background radiation steel required for sensitive medical and scientific equipment. The remnants of American, Australian, British, Dutch and Japanese warships have been the victim of these "metal pirates" (Browne 2017). At least 48 vessels have been salvaged/damaged, mainly associated with the Battle of Java Sea and Battle of Sunda Strait. Awareness and growing reaction to this transnational looting has not yet rendered a solution. The need for international cooperation is clear.

\section{Environmental Threats}

Ships and aircraft invariably have fuels on board which will negatively impact the marine environment, but the nature of unrestricted submarine warfare during WWII means that the issue is enhanced for the Western Pacific. In 2010, the Secretariat of the Pacific Regional Environment Programme (SPREP) initiated the Pacific Ocean Pollution Prevention Programme (PACPOL) following leakage from the tanker USS Mississinewa at Ulithi Atoll. In 2019, SPREP collaborated with the University of Newcastle and Major Projects Foundation to identify immediate threats in areas of western and north-west Remote Oceania. NOAA has also published an assessment of potentially polluting wrecks in federal waters (NOAA 2013). Other WWII sites have been assessed and mitigated, including USS Chehalis in American Samoa and SS Montebello off California. Ongoing work at USS Arizona provides long-term data on the remaining thousands of gallons of fuel oil deep within the battleship, led by the NPS Submerged Resources Center (Russell and Murphy 2004). Oil and environmental threats add a critical aspect to many WWII multidisciplinary UCH surveys, such as the USS Neosho and SS Cambridge projects. 
Safe diving practices require safety protocols for the recognition and reporting of UXO (unexploded ordnance armed/fired) and munitions (all ammunition products). The Japan Mine Action Service assisted the Republic of Palau in the mitigation of munitions at the Helmet Wreck site in Koror Harbor. Several unexploded shells have been documented at one of the Heritage Trail sites in Saipan. Moreover, both swimmers and divers have encountered UXO in Hawaiian waters, from .50 cal projectiles to $74 \mathrm{~mm}$ shells (UNESCO 2017). The multiagency project "Ordinance Reef, Wai'anae, Hawai 'i" was completed in 2007, assessing the potential for explosives leaching into the shallow near shore ecosystem (Cox et al. 2007). Several WWII shipwrecks in Australia are actively managed for the presence of munitions (I-124, M24, Florence D); recreational diving to the Japanese submarine I-124 is prohibited. SPREP's PACPOL strategy also addresses UXO issues related to World War II wrecks in the Pacific (UNESCO 2010).

\section{CONCLUSION}

The first section of this article focused on traditional indigenous heritage of Oceania, which consists of material culture (such as sites and artefacts) and located partially or wholly underwater, but much of the heritage related to the sea in Oceania is living heritage, which includes the sacred and spiritual relationships people have with the natural heritage. While the 2001 Convention is an important framework for the preservation of $\mathrm{UCH}$ in Oceania, its programmes and activities need to acknowledge living heritage components, or collaborate with programmes through other UNESCO Conventions, such as the Convention for the Safeguarding of the Intangible Cultural Heritage to ensure a holistic and contemporaneous approach to preserving $\mathrm{UCH}$. This is particularly important given the impact of climate change and sea level rise is having on many of the islands throughout Oceania. Whole islands and their cultural landscapes, which embody the islanders' cosmology and cultural identity will be consumed, not forgotten, but no longer lived.

The investigation of the Manila Galleon trade and its $\mathrm{UCH}$ provides an opportunity to understand large scale culture contact and trade within the Pacific region, inclusive of the cultures that existed prior to European intervention. Taking a maritime cultural landscape and seascape approach provides a broader view, inclusive of shipwrecks and a range of other 
related and relevant sites. Additionally, an approach that considers and even centres indigenous involvement, coerced or otherwise, in the trade provides a richer understanding of the global network and its impacts within Oceania and on local cultures. Considering and centering indigenous islanders can illuminate the ways in which contemporary religious and social institutions and customs, such as Catholicism, were accepted, resisted, and integrated into local culture. The Manila Galleon trade shaped the living heritage today. The for-profit and commercial adventures searching to locate the next treasure haul have thus far ignored the wider context of trade in Oceania and continued to prey upon the economic needs of the island communities through the extraction of $\mathrm{UCH}$ that is embedded in their waters and part of their history.

The thousands of WWII shipwrecks and aircraft in this region comprise a widespread cultural landscape embodying the events and technologies and human losses of a cataclysmic period in modern history. WWII UCH has historical and archaeological values, and economic (heritage tourism) and memorial (war grave) values as well. There are patterns to the location and nature of the UCH resource reflecting the strategy of the campaign and the tactical choices of individual battles/landings. This brief overview can only highlight major resource types and mention some recent projects and issues; however, it is most important to understand that the legacy of WWII in the region is not simply the story of combat between two adversaries. The true context of the conflict also includes the infrastructure and supply chain supporting the front line, the upheaval of islanders and non-combatants, the destruction of previous life ways and reconstruction efforts, and the impacts to the environment that we live with to this day. WWII greatly impacted the living heritage today. The focus on discovering capital ships and submarines by outside projects ignores these connections to local communities and contemporary issues.

Is there a common factor in these three very different temporal components of $\mathrm{UCH}$ that could help facilitate collaboration and support understanding, research and preservation? All three can have relevance and benefits to local communities as their ways of life include the living heritage associated with the different temporal components, namely traditional cultural heritage, Catholicism (associated with the Manila Galleon Trade), and the legacy of WWII, including the post WWII neo-colonial administration, and cultural tourism. In context with the 2001 Convention, this living heritage is invisible and therefore marginalised by solely focusing on tangible UCH. This tangible UCH is also contested; the Manila Galleon 
trade has implications for island and islander history, and WWII properties have potential environmental impacts and heritage tourism benefits; but these are usually ignored by the commercial exploitation of galleon sites, and the deep ocean WWII discoveries by outside projects. The value and preservation efforts related to $\mathrm{UCH}$ in the Pacific in context with the 2001 Convention could use a more integrated and local community approach, incorporating the crucial role of living heritage and the tangible $\mathrm{UCH}$ that can reflect aspects of the cultural identity of those living in the Pacific. In doing this, maritime archaeology activities in the Pacific should be directed by local people - a Community Maritime Archaeology approach. This will prioritise the needs of the indigenous people of Oceania and Southeast Asia and their $\mathrm{UCH}$, and encourage the investigation of nonindigenous UCH efforts through local direction, engagement, and with locally beneficial outcomes.

The local community emphasis is part of a more holistic approach inherent in maritime cultural landscape analysis. The impact on indigenous lives and their cultural heritage in general should always be considered when investigating non-indigenous UCH. The UCH training programmes and projects that have been carried out in Guam, Saipan, Hawai $i$ and Chuuk are empowering indigenous people to implement maritime archaeology from their perspectives. The dichotomy is that after the training, for which funding is nearly always available, it is not followed up with long-term funding for projects. The 2001 Convention encourages partnerships and the collaboration with Spain, Japan, and the US, for example, are important in the investigation and preservation of nonindigenous $\mathrm{UCH}$, and the development of bilateral and multilateral treaties. These partnerships also need to collaborate on investigating, preserving and utilising indigenous $\mathrm{UCH}$, of which much is connected to living heritage, thus providing local relevance and benefits for contemporary people living in Southeast Asia and Oceania.

\section{ACKNOWLEDGEMENTS}

The authors would like to acknowledge the contributions of the UNESCO Office of the Pacific States (Apia, Samoa), as well as the University of Guam, University of Hawai ${ }^{i}$, and East Carolina University for facilitating $\mathrm{UCH}$ studies in the Pacific. 


\section{NOTES}

* Bill Jeffery is an Associate Professor, Anthropology, University of Guam and holds a $\mathrm{PhD}$ from James Cook University, Townsville, Australia. His primary interest is maritime archaeology, which he commenced in Australia before going on to work with the Federated States of Micronesia National Historic Preservation Office, and in Hong Kong. His interests are in researching traditional indigenous material culture and living heritage particularly in Oceania, revealing multi-vocality perspectives of underwater cultural heritage, developing community maritime archaeology, and highlighting how maritime cultural landscapes can reflect maritime cultural identities.

** Jennifer McKinnon is an Associate Professor in East Carolina University's (ECU) Department of History, Program in Maritime Studies. She received a BA in Anthropology from University of Florida and an MA and PhD in Anthropology from Florida State University. Her current research interests include WWII battlefield and conflict archaeology, public and community archaeology, heritage tourism, maritime cultural landscapes and seascapes, and Spanish colonial heritage. Prior to arriving at ECU in 2013, she was a Senior Lecturer in the Department of Archaeology at Flinders University in Adelaide, South Australia from 2004. Before moving to Australia, she was a Senior Underwater Archaeologist with the State of Florida's Bureau of Archaeological Research. She is a Research Associate with Ships of Exploration and Discovery Research and Vice Chair of the Advisory Council on Underwater Archaeology.

*** Hans Van Tilburg is a maritime archaeologist and historian for National Oceanic and Atmospheric Administration's Office of National Marine Sanctuaries, supporting the Pacific Islands region in resource assessments and preservation of underwater cultural heritage under federal jurisdiction. This includes cultural landscape studies and collaborative management with indigenous communities and native landowners. Hans has a BA from the University of California Berkeley (1985), MA from ECU's Maritime History and Nautical Archaeology programme (1995), and PhD from the University of Hawai i (2002), where he ran a graduate programme in maritime archaeology and history. He has served as a consultant for UNESCO's intangible cultural heritage initiatives and an instructor for UNESCO's Foundation Courses in Underwater Cultural Heritage. Currently, Hans is also co-chair for the Asia-Pacific Region UCH Conference (APCONF) and bureau member of the International Committee on Underwater Cultural Heritage (ICUCH).

1 Living heritage is used in place of intangible cultural heritage as it better exemplifies the customs and cultural practices used in daily living, including socio-cultural practices, belief systems, kinship, environment, food, traditional knowledge, trade, exchange and people. It is a common term used in Oceania to highlight the continuous connection between past and contemporary cultural practices. In Oceania, living heritage is not seen as intangible; it is a fundamental and essential part of living, and therefore the term "intangible cultural heritage" is not well recognised.

2 There are 14 independent countries and two (Cook Islands and Niue) that are in free association with New Zealand but have been recognised by the United Nations as having full treaty-making capacity. 


\section{REFERENCES}

Andriany. 2017. P-38 Lightning aircraft wreck in Lae-lae Waters, South Sulawesi, Indonesia. In Proceedings of the 3rd Asia-Pacific Regional Underwater Cultural Heritage Conference, eds. Fahy, B. et al. Honolulu: APCONF.

Angaro, E. and Madrid, C. 2017. The world of the Manila-Acapulco Galleons: The global and human context. Quezon City, Philippines: Vibal Foundation.

Applegate-Palmer, K. and Jeffery, B. 2014. Seabee junkyard: A holistic and locally inclusive approach to site management and interpretation. In Proceedings of the 2nd AsiaPacific Regional Underwater Cultural Heritage Conference, eds. Van Tilburg, H. et al. Honolulu: APCONF.

Babits, L. et al. 2011. Battlefield analysis: Six maritime battles in Maryland Revolutionary War and War of 1812. Stone Mountain GA: New South Associates.

Bellwood, P. 2006. Austronesian prehistory in Southeast Asia: Homeland, expansion and transformation. In The Austronesians, historical and comparative perspectives, eds. Bellwood, P., Fox, J. and Tyron, D., 103-118. Canberra: The Australian National University Press. https://doi.org/10.22459/A.09.2006.05

Browne, K. 2017. "Ghost Battleships" of the Pacific: Metal pirates, WWII heritage and environmental protection. In Proceedings of the 3rd Asia-Pacific Regional Conference on Underwater Cultural Heritage, eds. Fahy, B. et al. Honolulu: APCONF.

Budge. 2016. Pacific war online encyclopedia. http://pwencycl.kgbudge.com/C/a/ Casualties.htm (accessed 21 April 2020).

Buschmann, R., Tueller, J. B. and Slack, E. R. 2014. Navigating the Spanish Lake: The Pacific in the Iberian world, 1521-1898. Honolulu, HI: University of Hawai i Press. https://doi.org/10.21313/hawaii/9780824838249.001.0001

Campbell, J. and Gesner, P. 2000. Illustrated catalogue of artefacts from HMS Pandora wrecksite excavations 1977-1995. Memoirs of Queensland Museum, Cultural Heritage Series 2 (1): 53-159.

Cantelas, F. et al. 2017. Exploring the underwater archaeology of World War II. Oceanography Supplement 30 (1): 72-73.

Carson, M. T. 2014. Conclusions and implications of earliest Marianas sites. In First settlement of Remote Oceania, ed. Carson, M., 135-147. Springer Briefs in Archaeology, vol. 1. Heidelberg: Springer. https://doi.org/10.1007/978-3-319 $-01047-2 \_11$

Clark, G. and Winter, O. 2019. The ceramic trail: Evaluating the Marianas and Lapita West Pacific connection. In Debating Lapita: Distribution, chronology, society and subsistence, eds. Bedford, S. and Spriggs, M., 37-60. Canberra: ANU Press. https://doi.org/10.22459/TA52.2019.02

Cox, E. et al. 2007. Ordnance reef, Wai'anae, HI: Remote sensing survey and sampling at discarded military munitions site. Silver Spring, MD: NOAA National Marine Sanctuary Program.

Craib, J. 1986. Casas de los Antiguos: Social differentiation in protohistoric Chamorro society, Marina Islands. PhD diss., University of Sydney, Australia. 
De Leon-Bolinao, L. 2014. Disaster in the high seas: The Spanish expeditions in the Pacific in the sixteenth century. In Proceedings of the 2014 Asia-Pacific Regional Conference on Underwater Cultural Heritage, eds. Van Tilburg, H. et al. Honolulu: APCONF.

Delgado, J. P. et al. 2016. The lost submarines of Pearl Harbor. College Station: Texas A\&M University Press.

Dickinson, W. 2003. Impact of mid-Holocene hydro-isostatic highstand in regional sea level on habitability of islands in Pacific Oceania. Journal of Coastal Research 19 (3): 489-502.

Driver, M. 1983. Fray Juan Pobre de Zamora and his account of the Mariana Islands. The Journal of Pacific History 18 (3): 198-216. https://doi.org/10.1080/ 00223348308572468

1993. Cross, sword, and silver: The nascent Spanish colony in the Marianas. Mangilao, Guam: Micronesian Area Research Center.

Fish, S. 2011. The Manila-Acapulco Galleons: The treasure ships of the Pacific, with an annotated list of the Transpacific Galleons 1565-1815. Central Milton Keynes, UK: Author House.

Fitzpatrick, S. 2009. Transboundary nomination for Yapese Stone Money Sites in Palau and Yap. UNESCO World Heritage List. Pohnpei: FSM National Government.

Gilbert, D. 2016. The challenge of sustainability for Pacific Island village fisheries, a historical perspective. In Fishers in the Pacific: The challenges of government and sustainability, eds. Pauwels, S. and Fache, E., 221-253. Marseille: Pacific-Credo Publications. https://doi.org/10.4000/books.pacific.446

Gillilland, C. L. 1975. The Stone Money oy Yap: A numismatic survey. Washington: Smithsonian University Press.

Giráldez, A. 2015. The age of trade: The Manila Galleons and the dawn of the global economy. Lanham, MD: Rowan \& Littlefield.

Goddio, F. 1994. San Diego. National Geographic 186 (1): 35-57.

Guérout, M. and Veccella, R. 2006. Protection of underwater cultural heritage in French Polynesia: Fifteen years of work by Gran. In Underwater cultural heritage at risk, eds. Grenier, R., Nutley, D. and Cochran, I., 93-95. Paris: ICOMOS.

Hau'ofa, E. 1994. Our sea of islands. The Contemporary Pacific 6 (1): 148-161.

Horridge, A. 2006. The Austronesian conquest of the sea: Upwind. In The Austronesians, historical and comparative perspectives, eds. Bellwood, P., Fox, J. and Tyron, D., 143-160. Canberra: The Australian National University Press. https://doi.org/ 10.22459/A.09.2006.07

Hunter-Anderson, R. and Zan, Y. 1996. Demystifying the Sawei, a traditional interisland exchange system. ISLA: A Journal of Micronesian Studies 4 (1): 1-45.

Isorena, E. B. 2015. Maritime disasters in Spanish Philippines: The Manila-Acapulco Galleons, 1565-1815. International Journal of Asia-Pacific Studies 11 (1): 53-83.

Iwabuchi, A. 2017. Japanese shipwrecks and human remains from WWII. In Proceedings of the 3rd Asia-Pacific Regional Conference on Underwater Cultural Heritage, eds. Fahy, B. et al., 1071-1086. Honolulu: APCONF.

Jeffery, B. 2013. Reviving community spirit: furthering the sustainable, historical and economic role of fish weirs and traps. Journal of Maritime Archaeology 8: 29-57. https://doi.org/10.1007/s11457-013-9106-4 
2017. Submerged Second World War II in Chuuk, Guam, Pohnpei and Yap. In Research on good practice in the protection and management of WWII-related underwater cultural heritage in the Pacific small island states and territories, eds. The Pacific Underwater Cultural Heritage Pertnership, 53-73. Apia: UNESCO.

Jeffery, B. and Moran, V. 2007. Report on the development of Guam's submerged and maritime archaeology sites databases. Unpublished report for Guam Historic Preservation Office.

Junco, R. 2011. The archaeology of Manila Galleons. In Proceedings of the 2011 AsiaPacific Regional Conference on Underwater Cultural Heritage, ed. Staniforth, M., 877-886. Kingston, RI: Museum of Underwater Archaeology. . 2016. On a Manila Galleon of the 16th century: A nautical perspective. In Early navigation in the Asia-Pacific region: A maritime archaeological perspective, eds. Wu, C., Juncho, R. and Sanchez, M. L., 103-113. Singapore: Springer International. https://doi.org/10.1007/978-981-10-0904-4_6

Jung, S. V. 2001. Wings beneath the sea: The aviation archaeology of Catalina flying boats in Darwin Harbour, Northern Territory. MA diss., Northern Territory University, Australia.

Kennedy, J. 2005. Results of an archaeological survey and archival research of WWII coastal defenses on Tutuila Island, American Samoa. Haleiwa: Archaeological Consultants of the Pacific.

Kimura, J. 2019. Searching for the San Francisco (1609), a Manila Galleon sunk off the Japanese coast. In Archaeology of Manila Galleon seaports and early maritime globalization, eds. Wu, C., Juncho, R. and Sanchez, M. L., 173-184. Cham, Switzerland: Springer Nature. https://doi.org/10.1007/978-981-32-9248-2_10

Kirch, P. 1987. Lapita and Oceanic cultural origins: Excavations in the Mussau Islands, Bismark Archipelago, 1985. Journal of Field Archaeology 14 (2): 163-180. https://doi.org/10.1179/009346987792208493

2010. Peopling of the Pacific: A holistic anthropological perspective. Annual Review of Anthropology 39: 131-148. https://doi.org/10.1146/annurev.anthro .012809 .104936

Lally, J. 2016. Analysis of the Beeswax shipwreck porcelain collection, Oregon, USA. In Archaeology of Manila Galleon seaports and early maritime globalization, eds. Wu, C., Juncho, R. and Sanchez, M. L., 169-194. Cham, Switzerland: Springer Nature.

Lawson, T. 2018. Nan Madol, Kubary and the wreck of the Alfred. http://www.mediafire .com/file/61okcpclxvrof21/Kubary_2018_06_18.pdf (accessed 24 December 2020).

Lenihan, D. (ed.). 1989. Submerged cultural resources study USS Arizona memorial and Pearl Harbor national historic landmark. Santa Fe: National Park Service.

L'Hour, M. 1994. Construction Navale. In Le San Diego: Un Trésor sous la mer. Exhibition catalog of On a Retrouvé le trésor du San Diego, 118-153. Paris: Association Française d'Action Artistique - Réunion de Musées Nationaux.

Lickliter-Mundon, M. et al. 2018. Identification of a deep-water B-29 WWII aircraft via ROV telepresence survey. Journal of Maritime Archaeology 13 (2): 167-189. https://doi.org/10.1007/s11457-018-9200-8

Lyon, E. 1990. Track of the Manila Galleons. National Geographic 178 (3): 5-37. 
Mathers, W. 1990. Nuestra Senora dela Concepcion. National Geographic 178 (3): 39-52. Mathers, W. M., Parker III, H. S. and Copus, K. A. 1990. Archaeological report: The recovery of the Manila Galleon Nuestra Señora de la Concepción. Report to the Commonwealth of the Northern Mariana Islands Historic Preservation Office. Sutton, VT: Pacific Sea Resources.

Mathers, W. M. and Shaw, N. 1993. Treasure of the Concepción. Hong Kong: APA Publications.

McKinnon, J. 2017. Spanish colonial shipwrecks in the Commonwealth of the Northern Mariana Islands. In Proceedings of the 3rd Asia-Pacific Conference on Underwater Cultural Heritage, eds. Fahy, B. et al. Honolulu: APCONF.

McKinnon, J. F. and Carrell, T. L. 2015. Underwater archaeology of a Pacific battlefield: The WWII Battle of Saipan. Cham, Switzerland: Springer International. https://doi.org/10.1007/978-3-319-16679-7

McKinnon, J. and Raupp, J. 2011. Potential for Spanish colonial archaeology in the northern Mariana Islands. The MUA Collection. http://www.themua.org/collections/items/ show/1198 (accessed 19 June 2020).

Min, L. 2013. Fragments of globalization: Archaeological porcelain and the early colonial dynamics in the Philippines. Asian Perspectives 52 (1): 43-74. https://doi.org/ 10.1353/asi.2013.0002

Murphy, L. 1984. Submerged cultural resources survey: Portions of Point Reyes National Seashore and Point Reyes-Farallon Islands National Marine Sanctuary. Submerged Cultural Resources Unit. Santa Fe, NM: National Park Service.

NACH (National Archives, Culture and Historic Preservation). 2015. Nan Madol: Ceremonial Center of Eastern Micronesia. Nomination by the Federated States of Micronesia for inscription on the World Heritage List. January 2015. http://whc. unesco.org/en/list/1503/documents/ (accessed 24 December 2020).

Neyland, R. S. 2017. Naval history and heritage command-underwater archaeology in the Asia-Pacific region. In Proceedings of the 3rd Asia-Pacific Regional Underwater Cultural Heritage Conference, eds. Fahy, B. et al. Honolulu: APCONF.

NOAA (National Oceanic and Atmospheric Administration). 2013. Risk assessment for potentially polluting wrecks in U.S. waters. Silver Spring, MD: National Oceanic and Atmospheric Administration.

Nunn, P. 2007. Climate, environment and society in the Pacific during the last millennium. Amsterdam: Elsevier. https://doi.org/10.1016/S1571-9197(07)06001-6

Peterson, A. 2014. Making the first global trade route: The Southeast Asian Foundations of the Acapulco-Manila Galleon Trade, 1519-1650. PhD diss., University of Hawai ${ }^{1}$ at Mānoa, Hawai i.

Peterson, C. D., Williams, S. S., Cruikshank, K. and Dubé, J. 2011. Geoarchaeology of the Nehalem Spit: Redistribution of Beeswax Galleon wreck debris by Cascadia earthquake and tsunami ( A.D. 1700), Oregon, USA. Geoarchaeology: An International Journal 26 (2): 219-244.

Pigafetta, A. 1969. Magellan's voyage: A narrative account of the first circumnavigation. New Haven, CT: Yale University Press.

Quimby, F. 2012. The Hierro commerce: Culture contact, appropriation and colonial entanglement in the Marianas, 1521-1668. Journal of Pacific History 46 (1): 1-26. 
Rainbird, P. 2004. The archaeology of Micronesia. Cambridge: Cambridge University Press. https://doi.org/10.1017/CBO9780511616952

Richardson, M. 2001. Can the pilar be found? And what's in it? Deep in the Pacific a plunge for riches. New York Times, 14 June.

Rodgers, B., Coble, W. and Van Tilburg, H. 1998. The lost flying boat of Kaneohe Bay. The Journal of the Society for Historical Archaeology 32 (4): 8-18. https://doi.org/10.1007/BF03374269

Rogers, R. 1995. Destiny's landfall: A history of Guam. Honolulu, HI: University of Hawai'i.

Roth, M. and McKinnon, J. 2018. Unidentified planes sighted: The application of KOCOA military terrain analysis to aerial combat. In ACUA underwater archaeology proceedings, eds. Keith, M. M. and Evans, A., 181-186. New Orleans, LA: Advisory Council on Underwater Archaeology.

Russell, M. A. and Murphy, L. E. 2004. USS Arizona preservation project research rationale. Santa Fe: National Park Service.

Schurz, W. L. 1939. The Manila Galleon. New York, NY: E.P. Dutton \& Company, Inc.

Sheldon, C. B. J. and Orillaneda, B. C. 2019. Archaeological researches on the Manila Galleon wrecks in the Philippines. In Archaeology of Manila Galleon seaports and early maritime globalization, eds. Wu, C., Juncho, R. and Sanchez, M. L., 129-145. Cham, Switzerland: Springer Nature.

Smith, T. 2007. Wreck of the Japanese type 'A' midget submarine M24. Parramatta NSW: Heritage Branch NSW Department of Planning.

Spriggs, M. 2013. Oceania: Lapita migration. The encyclopedia of global human migration, 1-6. Wiley-Blackwell. https://doi.org/10.1002/9781444351071.wbeghm839

Taboroši, D. and Jenson, J. 2002. World War II artefacts and wartime use of caves in Guam, Mariana Islands. http://citeseerx.ist.psu.edu/viewdoc/download?doi=10.1.1 $.136 .3705 \&$ rep $=$ rep1\&type $=p d f($ accessed 24 December 2020).

Tan, A. 2020. Manila Galleons in the Commonwealth of the Northern Mariana Islands: An analysis of the cultural impacts on Santa Margarita and Nuestra Señora de la Concepción. MA diss., East Carolina University, Greenville, NC.

Thomas, N. 2006. Exchange systems, political dynamics, and colonial transformations in nineteenth century Oceania. In The Austronesians, historical and comparative perspectives, eds. Bellwood, P., Fox, J. and Tyron, D., 287-308. Canberra: The Australian National University Press. https://doi.org/10.22459/A.09.2006.14

Throckmorton, P. 1998. The world's worst investment: The economics of treasure hunting with real-life comparisons. In Maritime archaeology: A reader of substantive and theoretical contributions, eds. Babits, L. E. and van Tilburg, H., 75-83. New York, NY: Springer. https://doi.org/10.1007/978-1-4899-0084-5_9

Trusted, M. 2013. Survivors of a shipwreck: Ivories from a Manila Galleon of 1601. Hispanic Research Journal 14 (5): 446-462. https://doi.org/10.1179/146827371 3Z.00000000060

UNESCO (United Nations Educational, Scientific and Cultural Organization). 2001. Convention on the Protection of Underwater Cultural Heritage. https://unesdoc .unesco.org/ark:/48223/pf0000126065 (accessed 24 December 2020).

2010. Underwater cultural heritage in Oceania. Paris: UNESCO. https://unesdoc.unesco.org/ark:/48223/pf0000188770 (accessed 6 January 2021). 
2017. Safeguarding underwater cultural heritage in the Pacific: Report on good practice in the protection and management of World War II-related underwater cultural heritage. Paris: UNESCO. https://unesdoc.unesco.org/ark:/48223/ pf0000260457_eng (accessed 6 January 2021).

Van Tilburg, H. 2014. The local Pacific inventory: Maritime heritage resources in the main Hawaiian islands. In Proceedings of the 2nd Asia-Pacific Regional Underwater Cultural Heritage Conference, eds. Van Tilburg, H. et al. Honolulu: APCONF.

Van Tilburg, H. and Delgado, J. P. 2017. The unseen landscape: Inventory and assessment of submerged cultural resources in Hawai' $i$. Camarillo, CA: Bureau of Ocean Energy Management OCS Study BOEM 2017-021.

Von der Porten, E. P. 2019. Ghost galleon: The discovery and archaeology of the San Juanillo the shores of Baja California. College Station, TX: Texas A\&M University Press.

Wu, C., Juncho, R. and Sanchez, M. L. 2019. Archaeology of Manila Galleon seaports and early maritime globalization. Cham, Switzerland: Springer Nature.

Williams, S. 2014. A Manila Galleon in Oregon: Results of the "Beeswax Wreck" research project. In Proceedings of the 2nd Asia-Pacific Regional Conference on Underwater Cultural Heritage, eds. Van Tilburg, H. et al. Honolulu: APCONF. . 2018. The Beeswax wreck of Nehalem: A lost Manila Galleon. Oregon Historical Quarterly 119 (2): 192-209.

Willie, E. and Shing, R. 2017. The President Coolidge: A report by the Vanuatu Cultural Centre. In Proceedings of the 3rd Asia-Pacific regional underwater cultural heritage conference, eds. Fahy, B. et al. Honolulu: APCONF.

Wilson, B. M. et al. 2007. Corrosion studies on the USS Arizona with application to a Japanese midget submarine. The Journal of the Minerals, Metals and Materials Society 59 (10):14-18. https://doi.org/10.1007/s11837-007-0124-2

WHC (World Heritage Centre). 1997. Third Global Strategy Meeting: Identification of world heritage properties in the Pacific, Fiji. https://whc.unesco.org/archive/ 208inf8.htm (accessed 24 December 2020).

1999. Second World Heritage Global Strategy Meeting for the Pacific Islands region. UNESCO, Vanuatu. https://whc.unesco.org/en/events/595/ (accessed 24 December 2020).

Yamaguchi, T., Kayanne, H. and Yamano. H. 2009. Archaeological investigation of the landscape history of an Oceanic Atoll: Majuro, Marshall Islands. Pacific Science 63 (4): 537-565. https://doi.org/10.2984/049.063.0405

York, R. and York, G. 2011. Slings and slingstones: The forgotten weapons of Oceania and the Americas. Kent, Ohio: The Kent State University Press. 